\title{
Sex, Drugs, Rock \& Roll, and the University College Lit: The University of Toronto Festivals, 1965-69
}

\author{
Charles Levi
}

In the late 1960s, the University College Literary and Athletic Society (the Lit) sponsored three festivals devoted to "Pop" art, psychedelia, and propaganda. As part of the 1967 festival, the Lit unsuccessfully attempted to have Timothy Leary visit to discuss the usefulness of LSD. This paper explores the festivals at University College, the controversy they created, and their successes and failures as cultural events, within the context of the history of student protest in Canada and the attempt to meld extra-curricular and counter-curricular activities in the 1960s as part of a wider search for "relevance" at the University of Toronto and in Canada as a whole.

À la fin des années 1960, le Cercle littéraire et athlétique du Collège universitaire de Toronto parraina trois festivals consacrés au Pop art, à l'univers psychédélique et à la propagande. Lors du festival de 1967, le Cercle essaya sans succès d'avoir comme conférencier Timothy Leary pour discuter de l'utilité du LSD. Ce texte examine les différents festivals du Collège universitaire, la controverse qu'ils suscitèrent, leurs succès et leurs échecs en tant qu'événements culturels. Cette analyse se situe dans le contexte de l'histoire des protestations étudiantes au Canada et des tentatives de fusionner les activités para académiques et contre-culturelles de la décennie 1960. Elle fait partie d'une recherche plus large de " pertinence " à l’Université de Toronto et au Canada dans son ensemble.

Dr. Timothy Leary got only as far as the Detroit/Windsor Tunnel in February, 1967. Despite attempts by a group of University of Toronto students to have him speak on campus, he appeared only on audio-tape. The planned visit is rarely mentioned in scholarship on Leary, but it is an interesting side-bar in Canadian university history, and has not to date been placed in its historical context. Canadians in the 1960s, especially Canadian university students, were attempting to come to terms with an emerging youth counter-culture, which was partially based on experimentation with mind-altering substances such as marijuana and LSD. This paper will study one student organization - the University College Literary and Athletic Society at the University of Toronto - and its efforts to integrate this counter-culture into the regular extracurricular life of a university. 
The invitation to Dr. Leary in 1967 continued a long-standing tradition. Student groups in Canada had invited controversial speakers onto university campuses as early as 1895, when the agnostic Alfred Jury and the socialist Phillips Thompson had been scheduled to debate each other as part of the program of the student-run University of Toronto Political Science Association. ${ }^{1}$ In the 1930s, controversial political leaders such as the communist Tim Buck and the fascist Adrien Arcand would be invited to speak on the McGill campus, ${ }^{2}$ and in the late 1940s "Red Dean" Hewlett Johnson of Canterbury, a prominent Anglican but also an apologist for the Soviet Union, visited Canadian campuses. ${ }^{3}$ Examples of controversial student speakers could be multiplied tenfold from this short list.

The invitation of Leary, however, took place in a different context than the previous examples. Leary was to participate in a psychedelic festival organized by the University College Literary and Athletic Society. He was not a single speaker, but part of a much larger program of speakers on a comprehensive topic. By 1967, this might not have seemed out of place - the middle 1960s saw the rise of the "teach-in," where groups of speakers were invited to a campus to cover related topics on a single theme. The University of Toronto held its first such gathering in 1965 on international revolutions. ${ }^{4}$

There would be no need to focus on the University College Festivals if they had not crossed a significant line in the history of student discussions of controversial ideas. By inviting Leary, the students of University College had moved from traditional extracurricular pursuits into a new realm, that of the counter-culture. Leary was more than a controversialist, and more than a politician with a subversive world-view - Leary represented a culture of LSD and dropping out of society far beyond what most Canadians considered an "acceptable" level of controversy.

Historians have written a fair amount on the nature of student protest in Canada, but not so much about counter-cultural protest. The oversight is not surprising, as there has been almost nothing in the history of student activities at universities that could be counted in this category. A brief itemization of student protest in Canada

1 Michiel Horn, "Students and Academic Freedom in Canada," Historical Studies in Education 11, 1 (1999): 5.

2 Paul Axelrod, Making a Middle Class: Student Life in English Canada during the Thirties (Montreal and Kingston: McGill-Queen’s University Press, 1990), 137.

3 Horn, "Students," 12-13; see also Reg Whitaker and Gary Marcuse, Cold War Canada: The Making of a National Insecurity State, 1945-1957 (Toronto: University of Toronto Press, 1994), 366-67.

4 Martin Friedland, The University of Toronto: A History (Toronto: University of Toronto Press, 2002), 527-28. 
should make this clear. Students have protested in Canada in defence of individual professors and administrators - they did so for George Weir at Queen's University in $1863,{ }^{5}$ William Dale at the University of Toronto in 1895, ${ }^{6}$ and William Adair at McGill University in $1939 .^{7}$ They also occasionally have protested against their professors, as with George Hunter at the University of Alberta in 1949. ${ }^{8} \quad$ Students have protested against cuts to grants to their institutions, for example at the University of British Columbia in 1932 and at the University of Western Ontario in 1939. ${ }^{9}$ They have rallied against raises in student fees, as at the University of Toronto in $1947 .{ }^{0}$ None of these could be counted as counter-cultural in its aim or effect.

Then there are cases of student protest that are closer to counter-cultural activities. Students who in the 1880s and afterwards protested in favour of or against the admission of women to Canadian universities were, no matter which side of the argument they took, at odds with elements of Canadian cultural thought. Those in favour of admitting women were advocating a form of feminism, and those against were defending a more conservative image of the proper role of women in society. ${ }^{11}$ Either position, it could be argued, was counter-cultural. In the 1930s, the Student Christian Movement led services for Remembrance Day that directly conflicted with those sponsored by the universities. ${ }^{12}$ These, and other student peace actions of the time, ran counter to Canada's traditional ties to imperial defence and unity. Similarly, the efforts of students in the Combined Universities Campaign for Nuclear Disarmament in the late 1950s and early 1960s ran counter to the role of Canada as part of the North Atlantic Treaty Organization and thus party to the needs of hemispheric defence against a perceived threat from the Soviet Bloc. ${ }^{13}$ In all of these

5 Michiel Horn, Academic Freedom in Canada: A History (Toronto: University of Toronto Press, 1999), 16.

6 Horn, "Students," 6.

7 Charles Levi, "Decided Action Has Been Taken: Student Government, Student Activism and University Administration at the University of Toronto and McGill University, 1930-1950” (unpublished M.A. major research paper, York University, 1994), 64.

8 Horn, Academic Freedom, 196.

9 Axelrod, Middle Class, 139.

10 Charles Levi, "Intimidating the Legislature: The Student Fees Protest of 1947 and its Aftermath,” unpublished paper, York Graduate Student Conference, 1997.

11 Sara Burke, "New Women and Old Romans: Co-Education at the University of Toronto, 1884-1895," Canadian Historical Review 80, 2 (1999): 221-26, 231-33, 240-41. 12 Axelrod, Middle Class, 140-41.

13 Doug Owram, Born at the Right Time: A History of the Baby Boom Generation (Toronto: University of Toronto Press, 1996), 218-19; Steve Hewitt, Spying 101: The RCMP's Secret Activities at Canadian Universities, 1917-1997 (Toronto: University of Toronto Press, 2002), 90, 93-94. 
cases, Canadian university students advocated policies significantly different from mainstream opinion. ${ }^{14}$ All of these, however, were single issues. None of them has been called counter-cultural by previous historians because they do not contain the final element that such a movement requires. To be counter-cultural, as Leary said in the 1960s, requires a complete break with societal norms. A student could protest the bomb and still be otherwise an upstanding member of society. To embrace psychedelia and LSD required a different view of society, one that emerged on university campuses only in the 1960s.

That decade encompassed a period of great turmoil in universities, most significantly in the United States but also in France, the United Kingdom, and to a lesser extent worldwide. Very few places were immune to its effect, not even Canada. Although the Canadian experience of the 1960s was largely without violent protest, campus disturbances did occur, with significant effects on university governance and policy.

Scholars in Canada have begun to build a theoretical framework for understanding the 1960s, based on North American demographic trends connected to the baby boom. Doug Owram discusses how this cohort not only strained the resources of Canadian universities but also disturbed the "old traditions" of these institution, which were formed in the 1920s. The baby-boom generation had already created a distinct youth culture. ${ }^{15}$ It had reshaped the Canadian high school and would, in the 1960s, reshape the university.

In this process of change, nothing was to be considered sacred. The curriculum, especially, found itself under attack. Patricia Jasen has noted that throughout adolescence this generation was told that higher education was to be "financially and spiritually rewarding for both the individual and society at large."16 Such expectations could not be sustained in the classrooms of the 1960s, with high enrolments and courses that seemed to have little connection to one another or to the society outside the walls of the academy, except in certain specialized disciplines where the university seemed to be nothing more than a slavish lackey of capitalist manipulation. ${ }^{17}$

14 This account leaves out, for reasons of space, the role of various campus newspapers in publishing controversial opinions. There is, perhaps, no controversial cultural subject in Canada that has not been written about in a student newspaper. For this, see Horn, “Students," 16-24.

15 Doug Owram, Born at the Right Time, 180-83.

16 Patricia Jasen, “' In Pursuit of Human Values (or Laugh When You Say That)': The Student Critique of the Arts Curriculum in the 1960s," in Youth, University and Canadian Society, ed. Paul Axelrod and John G. Reid (Montreal and Kingston: McGill-Queen's University Press, 1989), 250.

17 Ibid., 250-51. 
This dichotomy between the aims of the university and the actual education students were receiving led to alienation, frustration, and a new search for "relevance," something that would bring the university more into line with the claims it was making. The mechanisms used to bring about these changes were increasingly those of mass protest, and, as Owram points out, "any number of incidents could, with little warning, create major

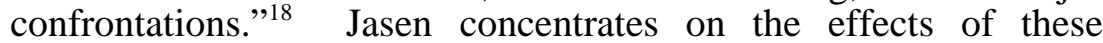
challenges on the university curriculum, but the quest for "relevance" also had an effect on the extra-curricular organization of student life.

As other scholars have noted, very few of the problems of the 1960s could have been forecast in 1959. ${ }^{19}$ In fact, in 1958 the University College Literary and Athletic Society had very calmly orchestrated a change in its structure that appeared to strengthen it. Founded in 1854 as the University College Literary and Scientific Society, it had focused its activities for much of the nineteenth and early twentieth centuries on the promotion of oratory and belles lettres in the same manner that such societies in the United States had operated in the early nineteenth century. James McLachlan has noted how these societies in the United States promoted a humanist culture in a university environment that might be otherwise intellectually stultifying. ${ }^{20}$ These oratorical activities were also well suited to the training of students who would, on graduation, become members of "talking” professions - lawyers, clergy, and teachers. By the beginning of the 1920s, however, this model of organization had become archaic, and the Society re-organized itself as the University College Literary and Athletic Society. It phased out debating and other oral activities and replaced them with cultural pursuits - the organization of student dances (including the annual Arts Ball), a student musical review entitled the University College Follies, the promotion of several literary journals under various names, and, in 1954, a campus newspaper, the Gargoyle. ${ }^{21}$ These new activities were more in tune with the desires of the students of the era, and also connected to the notion of career training. More graduates in the twentieth century were pursuing careers in, for example, accountancy and life insurance, which required experience in administration. This experience could be practically gained

18 Owram, Born at the Right Time, 239.

19 Helen Lefkowitz Horowitz, "The 1960s and the Transformation of Campus Cultures,” History of Education Quarterly 26, 1 (1986): 10.

20 James McLachlan, "The Choice of Hercules: American Student Societies in the Early $19^{\text {th }}$ Century,” in The University in Society, ed. Lawrence Stone, Vol. 2 (Princeton: Princeton University Press, 1974), 474, 480, 491.

21 The Literary and Scientific Society had briefly operated the main campus paper, the Varsity, but by 1900 it was no longer under the Society’s jurisdiction. 
through overseeing budgets for various cultural activities, and after 1921 the Literary Society (hereafter the Lit) received a mandatory annual fee from each student registered at the college.

And in 1958 the Lit solved one of its more pressing problems. Until that year, it had been a male-only organization, despite the fact that women had been admitted to the college in 1884. Though over the years there had been several attempts to gain their membership in the Lit, this had been resisted, partially on the grounds of prestige, and partially as part of a reflexive idea common to immature young men that girls were either "icky" or too domineering. This was expressed in less blatant terms, one student writing in the university newspaper, the Varsity, in 1949 that "the differences in attitude between the men and women are so fundamental and pronounced that the only realistic answer to the principle of amalgamation is 'No.",22 Another male student, before walking out of a joint meeting between the Lit and the University College Women's Undergraduate Association (WUA) in 1950, asked, "Shall we be hen-pecked? Are you willing to be under the domineering thumb of a woman?" and was not discouraged by a loud cry of "Yes!" from the crowd. ${ }^{23}$ By 1957 the rhetoric had somewhat softened and the Gargoyle was musing about "the pointless separation of the leadership" into two organizations. ${ }^{24}$ After ten years of protracted debate, the Lit amalgamated with the WUA to form a united society for the entire college. It is true that both organizations were by the late 1950s experiencing perpetual problems with getting students to come out for meetings, but the hope was that the new co-educational environment would spur greater interest, and the elections for the first amalgamated executive of the Lit brought more than half of the college students to the polls for the first time in recent memory. ${ }^{25}$

At the same time, however, a new cultural philosophy emanating from the highest levels was being expounded at the university. Claude Bissell, the new president of the University of Toronto in 1958, had attended University College in the 1930s and believed that its strength resided in individual initiative, not in collective activity. In his opening address to students and staff in September 1958, he urged students to assert their right to be "angular" instead of "spherical." He declared, perhaps to the

\footnotetext{
22 Varsity, Jan. 10, 1949.

23 Ibid., Nov. 30, 1950.

24 Gargoyle, Feb. 14, 1957.

25 Varsity, Feb. 20 and March 5, 1958. For more detail see Charles Morden Levi, "Where the Famous People Were?: The Origins, Activities and Future Careers of Student Leaders at University College, Toronto, 1854-1973” (Ph.D. diss., York University, 1998), 419-34.
} 
dismay of any Lit executive members in the audience, that "the men and women who have given the greatest leadership in society following their graduation have not been, I assure you, the campus politicians, the 'all round' students. They have been those who came here with intellectual passion and who made this passion the centre for their development."26 This idea, which Bissell reiterated in a 1959 speech, departed radically from the ideology of those who had come before him at the University of Toronto. ${ }^{27}$

In this ideological framework, the Lit's budget allocations for athletic equipment, campus cultural clubs, and dances seemed increasingly to be a waste of student fees. In 1963, the Gargoyle declared "there is no reason for buying people hockey sticks out of common funds if they want to play hockey, or subsidizing their dance tickets if they like expensive dances - why force serious students to support other people's pastimes."28 Many students turned away from the Lit altogether as a force on campus, election turnouts diminished, and acclamations to the executive became more common. The Lit responded to this pressure the same way it had in past generations - by refocusing its activities. If "relevance" was what students wanted, then certainly the Lit could rise to the challenge. Economics also played into its hands: student enrolments in the 1960s rose dramatically, and each student who paid fees into the Lit and did not receive services from it added to a pool of reserve money that the Society could spend on more ambitious projects.

The Lit was thus well placed to inaugurate a series titled "Current: Man in the Modern Age," which consisted of lectures and discussions presenting "questions relevant to the personal development of the undergraduate student," a concession to the new spirit of "angularity." Prominent campus professors, such as Emil Fackenheim and Northrop Frye, participated in the initial program in 1963, and by 1965 the increasingly popular series was importing prominent scholars from the United States, such as Arthur

26 Claude Bissell, “Angular, not Spherical,” in Bissell, The Strength of the University (Toronto: University of Toronto Press, 1968), 15.

27 This view was not necessarily shared by all university presidents in the 1960s. Escott Reid at Glendon College, for example, declared in 1967 that Glendon "needed students who questioned and rebelled against the established social order to produce a fruitful kind of intellectual ferment": see Alyson King, "The Glendon College Experiment," in Escott Reid: Diplomat and Scholar, ed. Greg Donahy and Stéphane Roussel (Montreal and Kingston: McGill-Queen’s University Press, 2004), 114. Reid had been a student activist in the 1920s; Bissell had pursued a more "angular" route in the early 1930s; see Horn, "Students," 7; Claude Bissell, Halfway up Parnassus: A Personal Account of the University of Toronto, 1932-1971 (Toronto: University of Toronto Press, 1974), 14-16. Bissell, as will be seen later, was forced to reconsider his late 1950s views by the end of the 1960s.

28 Gargoyle, Feb. 21, 1963. 
Schlesinger Jr. and Eugene Rabinovich. ${ }^{29}$ Their speaker's fees are not known, but they most certainly cost more than a few hockey sticks. Up until this point, the Lit had not moved very far from traditional patterns of student activities discussed earlier in this essay. Certain imaginative students now stepped in to divert the resources of the Lit more aggressively into culturally "relevant" directions.

Thus began the festival era at University College. Gail Dexter, then 20 years old, was the animating figure behind the first festival. Dexter would, in current terms, be considered something of a prodigy. At the age of 18 she had been hired by the Toronto Star as an art critic, and she had covered the Mariposa music festival for that newspaper. She had also attended the Newport Jazz Festival. Familiar with both art and the festival idea, she was encouraged by senior students to run for office in order to "turn around the image" of the Lit. Dexter ran and won. She had previously, during a session connected with a teach-in on Vietnam, noticed the drab, institutional nature of the University College Refectory, a banal addition to a historic building. One of her main goals was to redecorate this space. ${ }^{30}$

In October, 1965, the Lit approved a proposal by Dexter to hold a "Pop" Arts festival. This was to replace, for all time, the annual Arts Ball, a dance the Lit had sponsored since 1927. The opposition to the Arts Ball was a critical factor in the development of the festival. As Gail recounts it, the traditional method of decorating a large space was the "Prom" approach, to take a gymnasium and transform it into a kitschy dream "castle." This was, to her, "false consciousness," and she proposed instead that a supermarket be installed in the building, thus taking a "real" space and reproducing it out of context for shock value. Gail sold the idea to Dominion Stores, which gladly donated the material in exchange for free advertising. The festival was planned for January 20-22, 1966, and as the Varsity previewed it in December 1965, it was to capture "the vitality of modern life culminating in the Saturday reconstruction of the total modern cultural environment (which it would seem, is orgiastic)...Those who attend the Festival will be exposed to such aspects of modern popular culture as supermarket decor, fashion shows, a go-go dancers and electronic music, and slices of life drama." This was not to be frivolous, the paper continued, and was to be seen "from a new artistic, or culturally analytic perspective." 31

29 Varsity, Nov. 9, 1962; Gargoyle, Feb. 9, 1965.

30 Interview with Gail Dexter Lord, March 18, 2005.

31 Varsity, Dec, 9, 1965; interview with Gail Dexter Lord, March 18, 2005. 
The festival attracted serious notice, and was officially opened by the Canadian Secretary of State, Judy LaMarsh. LaMarsh declared that she "was astonished that undergraduates could produce such a finished, polished exhibition," and she happily showed to a Toronto Star reporter the Batman and Robin portrait she purchased for fifteen dollars. ${ }^{32}$ Barry Hale of the Toronto Telegram did his best to describe to readers the "total environment": an amalgam of continuous television commercials; a reproduction of a supermarket arcade; comic book and movie poster art; more serious art by the likes of Lichtenstein, Larry Peons, and Michael Snow; a tape loop of electronic music including "sound collages of street noises"; and a continuous rock and roll concert by a campus group, the Modes, complete with go-go girls and matched sets of models who "frugged and froze" while demonstrating "The Granny Look, the Courreges Look, the Mod Look and the Op Look." All of this, Hale explained, was to show that the "traditional Renaissance division between the fine and applied arts, between high and low culture, is being bridged by the new media and the new technology.,33

The Pop festival was a success, generating $\$ 1,500$ in ticket sales that allowed it to cover all expenses, even if electrical malfunctions had caused two small fires on the Saturday night. ${ }^{34}$ Robert Fulford in the Toronto Star called it "one of the triumphs of the cultural season in Toronto." The only thing missing was an appearance by Marshall McLuhan, which Fulford declared was "like Karl Marx failing to show up for the revolution." Martin Knelman in the Globe and Mail waxed more poetic than political, declaring "in the rooms they come and go, talking of Marshall McLuhan."35 Despite the success, however, the festival was criticized from both sides. The Athletic Director of the Lit, Peter McCreath, declared that all the Lit had actually done was provide the money, administrative support, and clean-up crews to engage art, architecture, and music students from the entire university. In short, it was not a college event and not worthy of the Lit's support. $^{36}$ McCreath was correct. The festival had been a success for the university community but had not awakened the Lit's own constituents. The contrary opinion was that the Lit had not gone far

32 Toronto Telegram, Jan. 24, 1966; Toronto Star, Jan. 24, 1966.

33 Barrie Hale, “Judy and the Pop Fest,” Toronto Telegram, Jan. 24, 1966.

34 Varsity, Jan. 20 and Feb. 3, 1966.

35 Robert Fulford, “A letter from Popsville,” Toronto Star, Jan. 24, 1966; Martin Knelman, "The market and the media: pop cultists tune in," Globe and Mail, Jan. 24, 1966. For more on the connection between McLuhan and counter-cultural activities see Timothy Leary, Flashbacks: An Autobiography (Los Angeles: J.P. Tarcher, Inc., 1983), 248-52.

36 Varsity, Feb. 24, 1966. 
Judy LaMarsh opens University College Pop Festival, 24 January 1966

Source: York University, Clara Thomas Archives, Image \#1095 
enough in establishing relevance. As painter William Ronald declared during a concurrent panel at the Royal Ontario Museum (which he entered "wearing regal robes of crimson and ermine, and a horned beignet"), "the fact that university students have saturated themselves with it to the extent that they can put on this festival proves that as a movement, Pop is dead." ${ }^{37}$ An event that attracted a federal cabinet minister could seem by critics to be insufficiently counter-cultural.

The hurdles were overcome in the next year's festival, "Perception '67," plans for which began in 1966 under the direction of Jane Markowitz. Markowitz proposed that the Lit sponsor an "artistic psychedelic experience" that would incorporate "LSD Art," which she believed was being produced in New York City. ${ }^{38}$ It was with these ideas that Markowitz won a by-election in November 1966 for the position of Literary Director. By the end of that month plans were well in hand for her festival, which was to include the conversion of the University College cafeteria into a series of "environments...created by simultaneously projected images and recorded sound and each simulating one aspect of a psychedelic experience." This was to be supported by lectures in the College's Junior Common Room "presenting several authorities on LSD and other drugs." 39

Controversy erupted, however, when Markowitz introduced the Lit to Toronto artist Michael Hayden. ${ }^{40}$ Hayden outlined plans for an LSD festival that would include a talk by Dr. Timothy Leary. Although the Lit readily accepted Hayden's offer to negotiate with the psychedelic rock group the Fugs during his next visit to New York, some members balked at the direction the festival was taking. As one sober senior student remarked, "I'm not opposed to dealing with LSD in the festival...but I think University College should steer clear of any suspicions that it is promoting drug addiction." Markowitz promised her approach would be both balanced and clinical, but some Lit members still questioned "the morality of the whole thing." Perhaps the aptest comment was uttered by Lit Secretary Elaine Goldman, who asked, "Are we prepared...to accept the responsibility if people go out and take LSD afterwards and suffer psychotic attacks?" At this point seminar convener and Lit member Al Kamin stepped in and said that despite warnings from the University Health Service that the symposium might be used as propaganda, "the more liberal fellows that he had contacted

Toronto Telegram, Jan. 24, 1966.

Varsity, Oct. 9, 1966.

Gargoyle, Nov. 3, 1966; Varsity, Nov. 23, 1966.

Michael Hayden is in some sources referred to as Michael Hayden Towne. 
Jane Markowitz and Michael Hayden with element of the Mind Excursion Rooms, 7 February 1967

Source: York University, Clara Thomas Archives, Image \#1096 
tended to minimize the danger." The Lit did in the end approve the festival, including a concert with the Fugs and Allan Ginsberg. ${ }^{41}$

There was nothing unusual about the twenty-two men and five women executive members of the Lit in the academic year 19661967. Most of them had, like their undergraduate colleagues, been born between 1945 and 1949. Only three of them had been born before 1945, and the oldest of those, born in 1941, was only twentyfive years old. The youngest was seventeen. Half of them were the children of businessmen, at least six were children of professionals, and the rest had parents who were in clerical work or skilled trades. At least six, but probably more, were Jewish. ${ }^{42}$ These unassuming middle-class students, the same sort who amazed Judy LaMarsh with their ability to produce "polished" work, were wandering into the middle of a controversy. Well in advance of the conference they found themselves issuing a statement that the Lit was "conducting this symposium in the interests of education and entertainment and that it neither necessarily supports nor opposes the position taken by any of the participants." 43

Tickets sold quickly: 350, priced at $\$ 3$ and including the concert, went in six hours on the first day they were on sale, several to students at American universities. Many television programs and magazines also were reported to be highly interested in the festival, and a film documentary and book on the festival were also announced. ${ }^{44}$ The book, The Art of Ecstasy: An Investigation of the Psychedelic Revolution, by William Marshall and Gilbert Taylor, was published by Burns and MacEachern in 1967. Marshall and Taylor had already been contracted to publish a book on the subject,

41 Gargoyle, Nov. 24 and Dec. 15, 1966. Al Kamin is cited by Bob Rae as the man who first made him "aware of drugs"; see Bob Rae, From Protest to Power: Personal Reflections on a Life in Politics (Toronto: Viking Press, 1996), 29-30. For the general opinions of the University of Toronto Health Service, see Christabelle Sethna, "The University of Toronto Health Service, Oral Contraception, and Student Demand for Birth Control, 1960-1970," Historical Studies in Education 17, 2 (2005): 265-92.

42 University of Toronto Archives (UTA), A89-0011, Student Records of the Faculty of Arts, combined with University of Toronto student directories and city directory searches. The occupational breakdown for their parents is twelve businessmen, six professionals (doctors, lawyers, etc.), two clerks, a manager, a machinist, and five not known. University College had ceased collecting religious information on its students by this point; the number of Jewish students was determined from other sources. The names of the Lit members for that year (as all years) are listed on the wall of the Junior Common Room at University College. For the record, their last names are Agar, Dacks, Ennis, Firman, Freiman, Goldman, Gluskin, Hay, Jeffery, Kamin, Kassirer, Lightman, MacRae, Markowitz, Penney, Redman, Rubin, Sadinsky, Schlein, Sklar, Solomon, Steiner, Stutz, Treleavan, Warner, Weinstock, and Weisman. This author believes that seventeen of these are Jewish.

43 Toronto Telegram, Feb. 2, 1967.

44 Varsity, Jan. 18 and 30, 1967; 2,540 tickets were sold and the festival was declared sold out by early February: see Excalibur, Feb. 10,1967. Some of the tickets were later "scalped"; see Toronto Star, Feb. 10, 1967. 
and the festival was, to them, "a happy coincidence." Taylor was a film director and Marshall had an abiding interest in movies, but the documentary did not receive funding and filming never took place. ${ }^{45}$

Several snags developed with the program. In April of 1966, Dr. Leary had been convicted and given a 30-year sentence for transporting marijuana across the Mexican border. ${ }^{46}$ Although a petition to the U.S. government by ten members of the University of Toronto faculty gained Leary the right to come to Canada without fear of arrest for violation of his parole conditions, as a drug trafficker he was ineligible to enter the country. ${ }^{47}$ The faculty members made clear that they did not agree with Leary's views but agreed that "he would make a valuable contribution to the symposium" on the subject of "the effect of psychedelics and their relevance to contemporary society." ${ }^{48}$ One sociology professor, Kenneth Walker, had been earlier quoted to the effect that the symposium would provide a rare opportunity to "confront" Leary about his opinions. Walker noted that students were old enough to hear about LSD use, and "if the result of the symposium does discourage the use of LSD - as I hope - then we might know more about the drug. We must know what we are up against since we can't control it." 49 Despite these reasonable opinions, University President Claude Bissell refused to "place the principle of free speech...over every other principle"and, in his own words, stuck by “dusty legalism” and did not intervene. ${ }^{50}$ The Toronto Telegram, a notoriously conservative newspaper, did its own part by alerting immigration officials to Leary's proposed trip, and it was supported editorially by the usually more liberal Toronto Star, which declared that "there is the possibility of real harm, and even tragedy, if Dr. Leary induces some of his hearers to experiment with LSD.",5i

45 E-mail between William Marshall and the author, April 6, 2005; William Marshall and Gilbert W. Taylor, The Art of Ecstasy: An Investigation of the Psychedelic Revolution ([Don Mills, ON]: Burns and MacEachern Limited, 1967). Some references call the book a "best-seller." The book contains many photos and quotes from the Festival. Marshall and Taylor did make three films about drugs for the Ontario Ministry of Education in the late $1960 \mathrm{~s}$

46 Leary, Flashbacks, 242. This sentence was thrown out by the U.S. Supreme Court in 1968; see ibid., 278.

47 Despite this, Leary had been able to enter Canada in October 1966 for an interview with the Canadian Broadcasting Corporation; see ibid., 255.

48 Toronto Telegram, Feb. 6, 1967.

49 Ibid., Feb. 2, 1967.

50 Varsity, Jan. 16, 1967; Claude Bissell, Parnassus, 126; UTA, Office of the President (Bissell), A75-0021/84, file "Students' Administrative Council," correspondence between SAC President Tom Faulkner and Bissell, Feb. 1967.

51 Toronto Star, Feb. 6, 1967. 
Accordingly, the Canadian government declared in early February that Leary would be barred from Canada. ${ }^{52}$

The discussion of drugs, especially LSD, was also at the last minute vetoed by University College Principal Douglas LePan. LePan prohibited the use of college property for the sections of the festival that featured "users or advocates for the drug LSD," even if such panels were balanced. Organizers of the festival saw these moves as draconian, ${ }^{53}$ but LePan's fears were completely justified. As he wrote Bissell, "Each year a far from negligible number of our students had psychic breakdowns and had to withdraw and enter psychiatric wards. I remembered with particular vividness...an occasion almost a year ago when a first-year student had had a fullblown psychotic episode in my office, screaming, crying, singing, and I had had to call in turn his relatives, Dr. Wodehouse of the University Health Service, and finally the police."54 Bissell himself had been criticized by an inquest into the death by drug overdose of a student in 1964.

The festival was saved, however, by the intervention of younger staff members at Hart House, the University of Toronto's men-only student club. Hart House had opened in 1919 and had developed over the years a concept of "informal education" that encouraged student discussions on controversial topics, and indeed encouraged students to make mistakes, even publicly embarrassing ones. The House had sponsored Communist speakers in the 1930s and 1940s, its debaters had spoken out against militarism and imperialism, and in 1955 the House had been condemned by the Mayor of Toronto for a display of nude art. ${ }^{55}$ It was in keeping with tradition for Hart House to make its facilities available for the discussion of LSD, to the consternation of LePan and other university officials. However, they had no jurisdiction at the club and were powerless to prevent the festival from going ahead. ${ }^{56}$ Indeed, the night before the festival the House held a preview debate where all three experts agreed that LSD was cheap and widely accessible in Toronto, although at least one of the speakers, Sidney Katz, of the Toronto Star, said that while he had been

52 Toronto Star, Feb. 3, 1967; for a slightly different narrative of these events, see Marcel Martel, Not This Time: Canadians, Public Policy and the Marijuana Question, 1961-1975 (Toronto: University of Toronto Press, 2006), 41-42.

53 Varsity, Feb. 3, 8, 1967.

54 UTA, Office of the President (Bissell), A75-0021/59, “University College,” LePan to Bissell, Feb. 13, 1967.

55 Friedland, University of Toronto, 391. See also Ian Montagnes, An Uncommon Fellowship: The Story of Hart House (Toronto: University of Toronto Press, 1969); Hewitt, Spying 101, 53.

56 UTA, Office of the President (Bissell), A75-0021/059, "University College," Donald Forster (Vice-President, University of Toronto) to Bissell, Dec. 9, 1966. 
experimenting with LSD since 1953, such drugs "are not for people with problems, depressions, anxieties and most especially the young seeking a way to avoid the necessity of making decisions." ${ }^{\text {, }}$

The problems and anxieties of Canadian society, however, almost succeeded where the university had failed. The Lit learned that the Fugs had been denied rooms at Toronto Park Plaza Hotel because one of their entourage was unsuitably dressed, and they ended up staying with Alan Ginsberg at another hotel. A shipment of paraphernalia from a "head shop" in the United States was confiscated at the border, although the proprietors were allowed to continue on to the festival after being "grilled mercilessly." Also detained in transit was the electronics technician who was supposed to assist with a fashion show put on by New York avant-garde designer Dr. Joan "Tiger" Morse. ${ }^{58}$ By far the most comedic aspect was the desperate attempt of the organizers to get Dr. Leary, in any form, to the festival. They arranged a meeting in the WindsorDetroit tunnel to receive a photograph of Leary handing his taped comments over the border to anxious Canadian students. The students, and the university radio journalists who accompanied them, were under the impression that the underground tunnel was neutral territory. The moment Leary stepped off the bus in the tunnel, however, he was seized by Canadian immigration officials, and Al Kamin, who was supposed to drive him back to the University of Michigan, found himself "bodily thrown back into Canadian territory.” Leary was arrested in Detroit for violating his parole, but the tape was eventually produced by customs agents and was played at the festival. ${ }^{59}$

The festival then proceeded to a second fiasco. What was billed as a "psychedelic fashion show and a psychedelic jazz concert" in Convocation Hall proved to be neither. The band, the Stu Broomer Kinetic Ensemble, according to the Toronto Star, was roundly booed and bombarded with paper airplanes from the balcony after playing 50 minutes of "so-called jazz." The blow-byblow account of the evening noted that after ten minutes people "were still waiting for the Stu Broomer group to get to the second bar of its music." As for the fashion show, "Tiger" Morse arrived late, "wearing silver boots, silver mesh stockings, a black vinyl

$57 \quad$ Toronto Star, Feb. 10, 1967.

58 Ibid., Feb. 11, 1967. For a profile of Morse from a Canadian perspective see Stan Fisschler, "Tiger burning bright in a dress full of light," Toronto Star, Jan. 30, 1967.

59 Varsity, Feb. 13, 15, 17, 1967; Toronto Telegram, Feb. 13 and 14, 1967; Toronto Star, Feb. 9, 13, 1967. See also "Dr. Leary Arrested by Custom Officials," The New York Times, Feb. 15, 1967. A slightly edited version of Leary's taped remarks is reprinted in Marshall and Taylor, Art of Ecstasy, 82-103. Some press reports contradict others on the contents of this paragraph, especially those sections relating to who was kicked out of which hotels in Toronto. Leary makes no mention of these incidents in Flashbacks. 
Timothy Leary at Customs, 14 February 1967

Source: York University, Clara Thomas Archives, Image \#1092 
miniskirt, a huge fur coat, and sunglasses (huge sunglasses - each lens is a good four inches in diameter)." Clearly believing she was the best-dressed person in the room, she surveyed the scene, declared the dressing rooms were so small that "my clothes are going to get sick," and the models chosen for the event were too professional for her natural-look fashions, and promptly entered the women's washroom, where she stayed for an hour and fifteen minutes. Two other fashion designers from Montreal and Toronto bravely carried on, but none of the truly avant-garde designs for which Morse was famous appeared. Morse appeared on the stage ten minutes after the event had finished, and was surrounded by press and angry event organizers. She asked the throng where she could hold a proper "happening" tomorrow night, and when Perception '67 officials said "anywhere but here!" Tiger retorted that she did not like working with "amateurs," and when the scrum continued, remarked that universities were "crummy" but she was determined to put on the show she had been invited to Toronto for. ${ }^{60}$ She did apparently put on that show somewhere on Saturday night (the place is not recorded in any available sources) but still left "hating Toronto," especially since three of her friends had been thrown out of the Westbury hotel. ${ }^{61}$

More successful were the "Mind Excursion Rooms," the creation of Michael Hayden. The rooms, ten in all, were designed to "produce in the person who experiences it some of the sensations produced by a psychedelic trip." Robert Fulford of the Toronto Star was one of the first through the exhibit shortly after it was completed at 6 a.m. the day it was to open. He declared that going through the rooms produced "a sort of mild freak-out" as he walked barefoot on gravel, waded through cotton wool, and walked "on a plastic bubble-cap material that makes exploding sounds as you put your weight on it." He also had to crawl "across a floor of photographs - blow-ups of deformed faces taken from a medical magazine" and then squeeze through a hole in the wall to move on. Fulford declared "the last room is the best of all. There you enter a kind of tunnel with green polka-dot walls. While music (or, anyway, some kind of sound) pulses at you, stroboscopic lights flash on and off. The effect is unexpected and disorienting. The people who are in the same room with you seem frozen, even when they're moving, they look like a series of still-photos. Their movements seem abrupt and non-human. The lights are blinding

60 Toronto Star, Feb. 11, 1967.

61 Ibid., Feb. 13, 1967. 
Mind Excursion Rooms, University College, Perception '67, 13 February 1967

Source: York University, Clara Thomas Archives, Image \#1097 
but the effect is so fresh that I could hardly bear to leave." Fulford conceded that "obviously it doesn't begin to approximate the effects of LSD" but he did say that as an experiment in disorientation, Mind Excursion worked, and Fulford envisioned an upgraded version of it transported to the Canadian National Exhibition as a "more sophisticated 1960s funhouse." Fulford also noted that Hayden claimed he had put together an \$80,000 exhibit with an outlay of only $\$ 1,500$ because of assiduous borrowing and scrounging. ${ }^{6}$

There were also various panel discussions of the use of LSD and its relation to art and culture. The star was Richard Alpert, one of Timothy Leary's associates. Much of the debate, according to psychiatrist Mark Eveson of the Emmanuel Convalescent Foundation of Aurora, Ontario, was "reduced to Boo Statements and Hurray Statements such as, I've had the drug; I like it. Or I haven't had the drug; I don't like it.” This seemed to be the case. Alpert and Dr. Humphrey Osmond, a pioneer LSD researcher in Saskatchewan (and the individual credited in the second edition of the Oxford English Dictionary as the inventor of the word "psychedelic"), defended the new drugs as another progressive step in technology. Alpert assessed the risks but declared, "If I have to wind up psychotic to break the status quo and get to a meaningful future, I'm ready." Psychiatrist Adam Rosenblatt, however, sad LSD pulled down the body's natural defences and questioned whether Leary knew what the drug was doing, and University of Toronto philosopher Charles Hanly called LSD "an opiate for the mentally lame, intellectually halt and morally blind," to the hisses of the crowd. ${ }^{63}$

Other discussions were more arcane. Canadian poet and University of Toronto writer-in-residence Earle Birney quizzed Allan Ginsberg on the alleged value of LSD to writers and creative artists. Ginsberg stated that the drug provided the same high that he had experienced through "art, or love-making or solitude or mountain-climbing," but that the LSD was far more reliably effective than any of them. Dr. Daniel Cappon, an associate of Marshall McLuhan, called the LSD revolution "a

62 Robert Fulford, "I went through the mind excursion - and liked it," Toronto Star, Feb. 11, 1967. For some photos of the construction of the room (and other aspects of the festival) see Marshall and Taylor, Art of Ecstasy, 119-46.

63 Toronto Telegram, Feb. 13, 1967. These quotes from Eveson and Hanly, as well as some of Osmond's remarks, are reprinted in Marshall and Taylor, Art of Ecstasy, 189, 192-93. 
significant search by youth to go beyond the stunted and stulted lives we lead" but said the drug itself was "an abomination." Another panel of legal experts, including Toronto's former narcotics prosecutor Arthur Whealy, tackled the possibility of relaxing Canadian laws against the use of marijuana, one member declaring that marijuana was as dangerous as motherhood, "and we surely don't want to eliminate motherhood."64

The crowds who turned up for Perception '67 were not entirely University of Toronto students. Journalists who covered the event made a point of mentioning prominent Torontonians who attended, such as coroner Morton Shulman and his wife, who arrived for the Friday night concert and fashion show. Also noted in passing were representatives of the hippie community then thriving in Yorkville Village, a short walk from the campus. The presence of visitors from the United States was also remarked on, as were their stories that Canadian border officials had a formal policy to interfere with their attendance. Journalists also noted, pointedly, that neither the Royal Canadian Mounted Police nor the Metropolitan Toronto narcotics squad showed any interest in the festival, the Toronto Star declaring "the only fuzz was on chins" and "there wasn't even a traffic cop at the scene, man." The entire security for the festival was entrusted to five campus security officers. ${ }^{65}$

After a day of controversy and "Mind Excursion," the Festival then had its Saturday night "happening." Two thousand people crowded into Convocation Hall to listen to Paul Krassner of New York's The Realist deliver a Lenny Bruce-inspired banter about "men's urinals, orgies, marijuana smoking, religion, genitals, and excrement." He was followed by Allen Ginsberg, who chanted some Buddhist religious texts "to the accompaniment of finger cymbals" and then, sensing the audience getting bored, launched into some of his psychedelicinspired poetry, which to Toronto Star writer Ralph Thomas "still sounded very much like the things Ginsberg writes cold sober." Ginsberg was followed by the main attraction, the Fugs, whose rock 'n roll songs about Vietnam, Timothy Leary, and subjects the Star considered unprintable met with tremendous applause. After the concert, an impromptu press conference was

64 Toronto Star, Feb. 13, 1967.

65 Ibid., Feb. 11, 1967. This contrasts with Al Kamin's strict warning to potential drug pushers that "the place will be swarming with policemen"; see Excalibur, Feb. 10, 1967; see also Martel, Not This Time, 50-67. 
stormed by appreciative fans of the rock group, and "as a result there were few pressmen and hundreds of long-haired youths and mini-skirted maidens asking all the questions." But by far the most important personage of the evening was Marshall McLuhan, who sat through the entire evening with his wife. McLuhan was "wearing a blinding, psychedelic third eye (light refracting discs) on his forehead," and after the concert was met by Allen Ginsberg, "Tiger” Morse, and members of the Fugs, who insisted on arranging a breakfast meeting for Sunday morning. ${ }^{66}$

Success breeds competition, and for those who could not get tickets to the Saturday night concert, additional psychedelic discussion was on tap. The Young Progressive Conservatives reacted to Perception '67 by staging a counter-event at the Royal Ontario Museum. Without Marshall McLuhan or the Fugs (they had Daniel Cappon instead), the forum drew 200 people. According to news reports, the panellists discussed the connection between technology, culture, and psychedelia, and were disrupted by a "spontaneous" concert by a group called the Vacant Lot, backed by gyrating go-go dancers. A nonplussed Gerry Gladstone, a sculptor, declared that "if this was psychedelia, he had another word for it. Two words...dull and boring...there is no way to use what these people are doing." Gladstone was also offended when one of the billed attractions, a flute and percussion concert to accompany one of his sculptures, failed to occur. The musicians never showed up. Another noshow was designer Allen Fleming, creator of the modern Canadian National Railway symbol. The Young Conservatives lacked the organizational panache of the Perception '67 team. ${ }^{67}$ However, their panel was only one part of a larger symposium they were hosting on "Canada: The Second Century." Indeed, after the Fugs had departed, the Young Conservatives had Convocation Hall booked for Sunday sessions on Youth and Society, and Nationalism and North America. ${ }^{68}$

The Literary and Athletic Society considered the festival yet another resounding success, although it lost $\$ 1,000$, mostly due to legal fees relating to the Leary question. Despite fears that the

66 Toronto Star, Feb. 13, 1967. The Star found the sexually charged language of the Fugs so objectionable that it refused even to print the names of some of the songs played. Excalibur, on the other hand, mentioned the song "Coca Cola Douche," and added "the most amazing thing about the Fugs is their beautiful, satiric, non-sniggering attitude toward sex and four-letter words in general.” See Excalibur, Feb. 17, 1967.

67 Toronto Star, Feb. 13, 1967.

68 Toronto Telegram, Feb. 11, 1967. 
student body would go LSD-mad, the only casualty was one student who passed out for half an hour in the "Mind Excursion Rooms." 69 Conservative critics, however, declared that Perception '67 was "a show of little real substance outside of its emotion charged issue.,"70 As the Telegram editorialized, "The discussion panels included a number of responsible people who warned of the dangers of indiscriminate use of the new (to our society at least) drugs. Unfortunately their message was blurred in the noise and lights and the bleats of outrage over the Immigration Department's barring of LSD high priest Timothy Leary."71 Claude Bissell remarked privately, "The festival was not so much an impartial and objective analysis of the use of drugs as a celebration of the psychedelic cult."72 Peter Hughes, in Canadian Forum, noted the disconnected nature of the festival. He commented that "the psychedelic cult is a symptom, not the cause, of wide-spread disillusionment with the American dream," but wondered "What does this mean to young Canadians who have never been part of that dream?" He also noted that Canadian students were "groping towards their own place in a juster [sic] society" and saw no need to drop out, even if they did have an interest in "happenings." As for the happenings, Hughes declared "none of the works and performances produced were in any real sense psychedelic, nor could they be. They were all products of conscious artistic purpose, which psychedelic drugs destroy." He went on, "the fault of LSD and other drugs is not that they produce bad art...but rather that they do not produce any art at all." ${ }^{73}$ Marshall and Taylor, in The Art of Ecstasy, add, "Its advocates make great claims for the creative value of LSD...But critics point to an inner vagueness which characterises steady acid users, and which seems to catch them up in the creativity of mere existence at the expense of achievement and everything else." ${ }^{\prime 4}$

Despite concerns about how the various themes combined, the Perception '67 festival did animate a large section of the university campus, and was sufficiently relevant to merit

\footnotetext{
69 Ibid., Feb. 13, 1967; but see Martel, Not This Time, 14-15.

70 Toronto Telegram, Feb. 11, 1967.

71 Ibid., Feb. 15, 1967.

72 UTA, Office of the President (Bissell), A75-0021/84, file “Students' Administrative Council,” Bissell to Tom Faulkner, President of the Students' Administrative Council, Feb. 1967. Bissell's remarks were based on impressions from other sources; he is not reported as attending any of the events,

73 Peter Hughes, “Tongue of Lead, Brain of Gold,” Canadian Forum, March 1967.

74 Marshall and Taylor, Art of Ecstasy, 115.
} 
comment from outside spectators as well. However, its success and controversy created unreasonable expectations for the future and for the director of the 1968 festival, Bob Rae (later premier of the province of Ontario), who was "determined to out-do the previous...show on psychedelic culture."75 The 1968 festival was called "(B)ABEL: or Society as Madness and Myth."76 As Rae related in his memoirs, he had planned to "link the themes of propaganda, advertising, and the madness and mayhem of modern culture." In view of the criticisms of the previous festival, these links were no doubt important to him. Instead, Rae learned more about the madness and mayhem of event planning.

Two artists had planned an ambitious "total environment" in the cafeteria, a sound-and-light show in Convocation Hall run through an intricate "black box," a film festival, and a concert by the Mothers of Invention. Because of budget constraints, Rae had to force the artists to cut back. Rae was further dismayed by the Mothers of Invention, who arrived three hours before their concert and told him they needed a new sound system in Convocation Hall, which Rae "broke every rule" to get. The Mothers concert violated the fire code, as the hall was stuffed beyond capacity. Faculty were outraged, and Frank Zappa ended the concert by "pouring shaving cream in every possible orifice of the huge organ at the front of the hall." The famed "black box" didn't work, the artists' "total environment" was incomprehensible (one critic noted that "the intellectual aspects of the environment are certainly very subjective, if not dubious”), ${ }^{77}$ and the festival ran a huge deficit, quoted in some sources as upwards of $\$ 6,500$. The Lit also became involved in three lawsuits over theft of equipment and other matters. ${ }^{78}$ Rae, in retrospect, considered (B)ABEL "an artistic success but a financial failure,"79 but as reviewers slyly noted, for all the hype about the festival, its most popular programming items were the films, and especially the silent classic, Birth of a Nation, hardly a shot in the arm for the backers of new, radical art. And even the film program was criticized as "an ambitious plan that never quite came off" because "the student organizers didn't know

Rae, From Protest to Power, 31.

Varsity, Jan. 29, 1968.

Brian Cruchley, "Say, who were Those Mothers I saw you with last night?"

Toronto Telegram, Jan. 29, 1968.

78 Rae, From Protest to Power, 31-32; Varsity, Jan. 29, 1968.

79 Interview with Bob Rae, March 9, 2006. 
quite enough about just what was on the films they were screening." 80

These problems led the Lit to seriously reconsider its commitment to the festivals. Although it was able to settle all the lawsuits out of court, the organization was now in debt. The 1969 festival never made it past the drawing boards. Its title, "Pornographia '69," was enough to garner a formal threat of university censorship and the suspicion of future legal problems. Plans were abandoned in November 1968, ending the festival era. ${ }^{81}$

The festivals brought the Lit directly into contact with the emerging counter-culture of the 1960s and the reactions of the larger community, and especially adult authority, towards it. Doug Owram has pointed to the reactions of campus officials to the growth of drug use on campus. Owram further states that the combination of drug usage, looser sexual morals, and unusual dress and appearance only became a counter-culture "when they were accepted as an integral intellectual and ethical movement."82 Certainly this was the case when they became the focus of multi-day conferences at University College in which they were treated with all due academic seriousness by the Literary Society.

Through the festivals the Lit achieved a reputation as a provider of campus-wide, "relevant" entertainment. ${ }^{83}$ By 1968, the festival impulse created at University College had spread to other places. When Glendon College held its "Year of the Barricade" conference in 1969 it combined the traditional teachin list of speakers with a concert by folk-singer Phil Ochs and street theatre performances by Theatre Passe Muraille and the Vancouver Street Theatre. ${ }^{84}$ Theatre Passe Muraille was linked to Rochdale College, which after its opening in October 1968 became the focus for drug acquisition and sale in the University of Toronto campus area, drawing thousands of curious youth to its 18-storey tower at Bloor and Huron streets every weekend.

\footnotetext{
80 Michael Walsh, "Birth of a Nation - (B)abel's best,” Toronto Telegram, Jan. 29, 1968.

81 Gargoyle, Oct. 10 and Nov. 21, 1968.

82 Owram, Born at the Right Time, 198-204.

83 See for example, Varsity, Oct. 20, 1967.

84 Pro-Tem, Oct. 14 and 29, 1969. York University held what it called the "York Festival" in November 1968, which included a concert by Gordon Lightfoot and the showing of "Roadrunner cartoons and classic films," but it also included intercollegiate sporting events with Queen's and Carleton and it lacked any psychedelic or mindexpanding elements; see Excalibur, Oct. 24, 1968.
} 
Rochdale, as well, would take up the festival idea with its "Inner Space Odyssey" summer festival of July 1969. ${ }^{85}$ At the onset of the 1970s, the counter-cultural ideas of the 1960s also were somewhat integrated into the mainstream. Doug Owram notes that pre-marital sex and rock music, two of the defining characteristics of this culture, had been "accepted by society as a whole" by 1973, and even "soft drugs" were less of a crisis, although they remained illegal. ${ }^{86}$

By 1968 as well, the nature of student activism had changed. Some of this was evident at University College, where the festivals led to direct conflicts with the college authorities, and to the integration of students into the governance of the college. In 1969, after protracted negotiations, students gained seats on the University College Council, which was responsible for all policy decisions at the college. ${ }^{87}$ Shortly after, Principal LePan resigned and four students served on the committee that chose his successor. ${ }^{88}$ Across Canada, students were taking places on college and university committees. ${ }^{89}$ Bob Rae, after cutting his teeth on the University College festivals, joined with Stephen Langdon to push for a Commission on University Government, which by 1971 had gained student representation on the new Governing Council of the University of Toronto. ${ }^{90}$ At other universities things would not go so peacefully. At Simon Fraser University in British Columbia, student activists centred in the Political Science, Sociology, and Anthropology Department would occupy university buildings in October of 1968; similar tactics would be used at McGill University in the spring of 1969. And at Sir George Williams University in Montreal in February 1969, simmering racial tensions would lead to two million dollars damage to that university's computer centre and the arrest of ninety-one people. ${ }^{91}$ At the University of Toronto, the

85 David Sharpe, Rochdale: The Runaway College (Toronto: House of Anansi Press, 1987), 64-65; see also Howard Adelman, The Beds of Academe: A Study of the Relation of Student Residences and the University (Toronto: Praxis Books, 1969), 187-98; Ralph Osborne, From Someplace Else: A Memoir (Toronto: ECW Press, 2003); see also Martel, Not This Time, 41, 68-69 for other events.

86 Owram, Born at the Right Time, 305-6; Martel, Not This Time, 188.

87 Varsity, Jan. 17, 1969; UTA, Office of the President (Bissell), A77-0019/003, LePan to Bissell, April 15, 1969.

88 Varsity, April 3, 1970.

89 See, for example, Stanley Brice Frost, McGill University: For the Advancement of Learning, Vol II, 1895-1971 (Montreal and Kingston: McGill-Queen’s University Press, 1984), 454-56.

90 Rae, Protest to Power, 32-33; Bissell, Parnassus, 160-78.

91 Hewitt, Spying 101, 146-65; Frost, McGill, 458-62. 
disruption of a speech by Clark Kerr in February 1969 caused Claude Bissell to reconsider his views on "angularity." Bissell notes in his memoirs his "concern about the possible use of force to gain student political goals," incidents at the University of Toronto into the 1970s which deepened this concern, such as the March 1970 occupation of Simcoe Hall to protest the lack of sufficient day-care facilities on campus. $^{93}$

This continued focus on direct action to achieve student goals meant that the Festival Era could not save the University College Lit. Even as the festivals were animating the campus, vote totals continued to drop at Lit elections and the rate of acclamation to positions increased. Before the 1967 festival, a Gargoyle editorial declared that there was no purpose for the continued existence of the Lit. ${ }^{94}$ After the festival, an editorial entitled "Reflections in a Cesspool" declared that "none of the candidates that served on this year's Lit brings to mind anything approaching imagination, drive, or competence."95 The editor was relieved of his position as a result, but the situation did not improve. After the allure of the 1960s waned, the entire Lit executive was acclaimed in February 1970, ${ }^{96}$ and by 1972 it could not find a single person to serve as treasurer, at which point a clever impersonator attempted to walk away with the entire $\$ 10,000$ budget for the society. ${ }^{97}$ This was followed shortly after by the collapse of the Gargoyle, which did not revive for four years.

The forces stacked against the University College Literary and Athletic Society in the 1960s were simply too strong. Founded on a 1920s vision of administrative organization of events for the College, it did its best to come up with more and more ambitious plans to attract the attention of a student body searching for "relevance." These plans attracted national (and in one case, international) attention but did not solve the problem of student alienation from "the establishment." In an age of mass protest, in which students mobilized in reaction to specific causes and issues, a continuing body unconnected to these

Bissell, Parnassus, 138-41.

Ibid., 150-54.

Gargoyle, Dec. 8, 1966.

Ibid., March 2, 1967.

Ibid., Feb. 27, 1970.

Ibid., Nov. 22, 1972. 
protests stood no chance of engaging sustained student interest. ${ }^{98}$ At the height of the 1960s, counter-curriculum trumped extracurriculum.

98 The Student Christian Movement suffered the same fate; see Catherine Gidney, $A$ Long Eclipse: The Liberal Protestant Establishment and the Canadian University, 19201970 (Montreal and Kingston: McGill-Queen’s University Press, 2004), 106-11. 